\title{
Young children as beings, becomings, having beens: An integrated approach to role-play
}

\author{
The new paradigm of early childhood allows for the construction of the child as \\ active agents able to comment on their own lives. Historically children have been \\ constructed using divergent discourses as either beings or becomings. More \\ recently they have been seen as complementary and a further temporal state of \\ having been allows for a richer description of the child. In play and role-play the \\ three temporal states can be observed and appear to inform the children's \\ understanding of complex world structures. This paper reports the research that \\ was conducted in two Early Childhood Education and Care settings in England. \\ The research was concerned with young children's experiences of play and role- \\ play in their early childhood setting. Observations and conferences demonstrate \\ the ways in which the temporal states are established in their play.
}

Keywords: role-play; sociology of childhood; temporal states; constructions of the child.

\section{Introduction: Shifting paradigms of early childhood in the 21st Century}

In this paper I consider the three temporal states of being, becoming and having been that are acknowledged by Cross (2008). The three temporal states impact on the child's identity and sense of self. Belonging is an emerging concept within early childhood education and care and is commonly linked with being and becoming and considered as a temporal dimension (Tillett and Wong 2018, Stratigos 2015). In this paper I adopt Cross' (2008) framework in order to understand and demonstrate young children's concept of themselves as human beings, becomings and having beens.

In sociological terms from the 1970s onwards a new paradigm for the study of early childhood emerged. The social status of children had previously been exceptionally low, they were perceived as being, dependents in need of socialisation (Mayall 2002). Considerations of childhood had been focussed on the universal rather than the 
particular (James, Jenks and Prout 1998). Children were conceived as irrational beings that needed to mature and become rational and were not afforded rights given their lack of rationality (Kay and Tisdall 2012). Adulthood was perceived as a time in which one's life became established, 'Once an adult had a stable job and a stable intimate relationship, there would be very few significant changes...' (Lee, 2001,7). It was set against this backdrop of assumption that the being and becoming divide developed (Uprichard 2008). The divide informed the relationship between children and adults, a relationship in which the child was constructed as in some way lacking or incomplete a becoming (Lee 2001). The, '...immaturity of children is a biological fact of life but the ways in which this immaturity is understood and made meaningful is a fact of culture...' (James and Prout 1997,7). In a becomings model the biological factors impact on the societal view of the child. In Western cultures children were considered vulnerable, in need of protection and inferior to the adults around them (Wyness, 2006).

Children who are seen as beings are considered active agents, social actors, competent, capable of co-constructing their lives and able to comment on things that affect them (James, Jenks and Prout 1998, Qvortrup 2004, Cosaro 2010). Through these new discourses of childhood in which children are constructed as being, they are, '...conceived of as a person, a status, a course of action ... in sum, as a social actor' (James, Jenks and Prout 1998, 207). There continues to be recognition that the child is not a static being, it has a past and a future; however, the new paradigm of being enables an understanding of the current state (ibid 1998). Likewise, the new sociology of childhood has developed in opposition to child development paradigms that, ‘...focus on adults and adulthood as the "gold standard" ...' Kay and Tisdall $(2012,181)$. Malaguzzi, one of the pioneers of the Reggio Emilia approach, argues for the need, '...to change the dominant image of young children from adults-in-the-making, 
irrational, incompetent beings, to capable people in their own right' (Ebrahim 2011, 121). He further argues that relationships are at the heart of the learning process and it is through these processes that the child can become aware that they are; continually reconstructing themselves - today they are not who they were yesterday (Malaguzi cited in Rankin 2004). This emphasis on the social and the cognitive brings together both sociology and developmental psychology. In this way children are recognised as capable and competent (James, Jenks and Prout 1998, Qvortrup 2004, Cosaro 2011). Sociological approaches that have viewed children as either, '... human 'beings, or human 'becomings' tends to involve conflicting approaches of what it means to be a child' not necessarily supporting the child's ability to develop a notion of their own identity (Uprichard, 2008, 304). Whilst historically these divergent discourses have been seen as conflicting, there is an argument for recognising the complementary nature of them (ibid 2008). In integrating these two images of the child as both being and becoming, the child is afforded greater agency. The child is a child in the present but they will be an adult in the future, even very young children appear to understand the concept and can articulate it. Seemingly discourses that focus on a becomings construction are fundamentally flawed in two ways (Uprichard 2008). Firstly, the focus on becoming impacts on the being, that which is happening now. Ostensibly '...how we conceptualise something in future may influence how we conceptualise it in the present' (Uprichard 2008, 304). Our expectancy of the future may also impact on the present (ibid 2008).

Secondly within a becomings model issues of competency are raised. Children are seen as incompetent, competency is something acquired in adulthood it is, ' $\ldots$ an adult characteristic, i.e. one that children cannot possess' (Uprichard, 2008, 305). The being child is constructed as self-competent, however, there appear to be two further 
problems with this particular construction of the child (ibid 2008). In the first instance, the being child is a mirror of the becoming child and this relationship maintains the existence of the becoming child and the hierarchical nature of the relationships involved (ibid 2008). In the second, the being child ignores the, 'future experiences of becoming adult', (Uprichard, 2008, 305). On the face of it whilst children are aware that they are growing up and changing, they are also aware that something of them remains the same. Uprichard (2008) suggests that a being model of childhood does not sufficiently address the temporality question, the model fails to consider future constructions of the child. A model of childhood that combines the two discourses, unifying the characteristics of dependency, usually associated with children, and competency, usually associated with adults, allows for a more effective discourse (Uprichard 2008). Children will not remain children forever; they will become adults of the future. The adults that they become is likely to be influenced by the childhoods that they have experienced, being and becomings both being affective.

\section{A third temporal state: beings, becomings and having beens}

A third temporal stance, 'having been', is suggested by Cross $(2011,26)$. The having been impacts both on the being and the becoming (Cross 2011). Whilst the dichotomy of being or becoming has been, to a greater extent, resolved by Uprichard (2008) the two terms would seem insufficient in demonstrating children's ability to articulate themselves and their experiences. In developing the third temporal stance Cross (20121) states that whilst Uprichard (2008) has created a useful complexity framework that incorporates the two previous discourses and clearly relates them to temporal states, there is a need for a third temporal stance which demonstrates how children are orientated in both the present and the future. Other researchers have discussed notions 
of the having been child; however, they suggest that most of this is research in which adults remember and comment on their childhoods (Conrad 2011 and Brannen 2004). The assertion that Cross (2011) makes is that children in both their current state of being as well as their future state of becoming are influenced by what has already occurred in their childhood and that we need to consider all three states of being in our construction of children given that it will be evident in their behaviours. Clearly, '... persons of any age have a valid claim to both being and becoming' (Cross 2011, 30). Very young children under 6 months who have been subject to neglect will demonstrate poor attachment that will be reflected in the ways in which they behave in every new situation (Bowlby 1952, Ainsworth 1970). Patterns or schemas will be laid down about each situation as it is encountered and these patterns or ways of behaving will inform the next time that a child meets a similar or new situation (Piaget 1959). So, whilst the notion that the past has a direct impact on the current and the future is not new, Cross (2011) has articulated this in a way that has not previously been seen and allows for new considerations of children's understanding and behaviours. She (ibid 2011, 31) suggests that, '.. in bringing this third term into consideration, it is important to also consider children's own capacity to experience themselves as a human having been.' It would seem reasonable to argue that any interaction in the present will be influenced by what has occurred in the past. Whilst very young children may not be able to effectively articulate their understanding of what prompts them to behave in a particular way in each situation, it would appear that their previous experiences will impact on their behaviours.

\section{Play: Beings, becomings and having beens}


Play and role-play opportunities provide demonstrable potential for children to be engaged in integrated way as beings, becomings and having beens (Cross 2011). In these play scenarios the integrated being, becoming and having been is in evidence (ibid 2011). Role-play allows for a creative 'mimesis', an imitative representation of nature or human behaviour that allows children to recreate aspects of their lives and explore them for themselves, thus making sense of the structures and ideas (Papadopoulou 2012). Role-play supports both self-expression and self-development. Children engage in imaginative play opportunities and through these activities they develop both cognitive and social and emotional skills that are often considered the prerequisites for learning (Leong and Bodrova 2005). Play is linked to memory, self-regulation, something necessary for learning to occur, oral language and symbol recognition. It provides opportunities for children to explore as beings, becomings and having beens. Broadhead and Burt (2012, 33 italics in the original) advocate open-ended play opportunities in which children can create their role-play in spaces that are the, '...whatever you want it to be place...' Imaginative play opportunities allow children to, 'connect with reality so that cultural meanings and objects residing in reality can be reworked' (Edwards 2011, 200). Likewise, role-play allows children to, '...layer the pretend world onto the real world...' (Sawyers and Carrick 2008, 139). Children constantly work and re-work these cultural meanings in animated ways that allow them to reorganize and make sense of their environment (Papadopoulou 2012). Where opportunities for role-play are fully developed, children are enabled to develop other skills including those related to; social development, mathematics, literacy and selfregulation (Leong and Bodrova 2012). Seemingly the, ‘... richer children's experiences are the more material they have to draw on to feed their imagination' (Edwards (2011, 201). Leong and Bodrova (2012) developed an approach to play that encourages 
children to Plan, to consider Roles, to use Props, to use an Extended time frame for their play, to use Language appropriate to the roles and to develop an appropriate Scenario (PRoPELS). Children draw on their knowledge, memory and previous experiences to enact their play scenarios, consequently developing the necessary skills to enter their social worlds, developing an understanding of the complex structures found within them and demonstrating that in play they are beings, becomings and having beens

(Papadopoulou 2012, Cross 2011).

\section{Methods}

In light of the above discussion this research project was developed to examine whether and in which ways children utilise the three temporal states of beings, becomings and having beens in their play and role-play in two pack-away settings.

\section{Ethics}

The project adhered to the EECERA (2014)

http://www.becera.org.uk/docs/EECERA_Ethical_Code.pdf code of ethics. Informed consent and on-going informed consent was sought and gained from the children throughout the project. At the start of the research period the parents and carers gave their informed consent to their children participating in the research and to them participating in the parent conference. Written consent, often in the form of simple mark making, was gained from the children at the outset of the work they demonstrated their understanding of what I was doing and their consent to participate in the research project they discussed what they would be doing saying that they would like to use the cameras, that they were happy for me to watch them playing or to play with them, that they would engage in a range of other tasks. On-going consent was not recorded, but consent was given by the children each time they worked with me. 


\section{Research Context}

Pack-away settings are ones that are situated in spaces such as church halls or village halls, non-permanent spaces in which it is necessary to set up and put away the setting on a daily basis. The two settings are considered to be pack-away settings; they operate in non-dedicated spaces, a church hall and a memorial hall. As role-play appears to provide particularly extensive opportunities for children to explore the world around them my intention was to examine whether through their role-play children explore their ideas drawing on the three temporal states of; being, becoming and having been.

\section{Research Design}

I adopted an ethnographical methodology, within an interpretive paradigm informed by critical reflection in which I recognise children as active agents in their own lives, capable of making comments about their experiences of their lives. Ethnographic studies have been used by Early Childhood researchers for a range of purposes and specifically to gain an understanding of children's experiences in particular settings and when researching play. Ethnography can, '...paint in the fine-grained reality of educational processes within early childhood settings' (Siraj-Blatchford and SirajBlatchford, 2001, 194). The data for ethnographical research are usually gathered using a range of different sources, with observation and informal conversations being seen as key (Siraj-Blatchford and Siraj-Blatchford 2001). The data of this project was gathered using a range of different methods which included observations, children's photographs and informal conversations. These approaches have been validated by other studies including: Clark et al (2014), Clark (2011), Cook and Hess (2007), Christensen (2004) and Clark and Moss (2001). Data was collected over a 7-month period; most children generated data over a period of between one and three months. I visited the two settings sequentially spending time getting to know the children before data collection began. 


\section{Participants}

The names of all children, practitioners and parents as well as the settings that they attend were anonymised and they have been given pseudonyms. The total sample was a group of 8 children aged between 3-years-3-months, to 4-years-1-month at the start of the data collection period. These children attended one of two early childhood settings; Homefell Nursery and All Hallows Pre-school, there were 4 children in each setting. In the vignettes that are included below three of the children; Penny, Caleb and Jack, are observed at play with their peers or participate in a conference activity with me. The children's ages were recorded at the beginning of the data collection period; Penny was 3-years-11-months, she lived with both parents and her younger brother who was less than a year-old. Penny was articulate and the setting reported that she was able to read a write beyond expectations associated with her age. Caleb was 3-years-6-months old; he lived with both his mother and father and was the youngest of four brothers. Caleb's father worked in a local shop and he was known to spend some time with his father there. Jack was 4-years-1-month and lived with his mother and younger brother. His parents had separated a few months before the start of the data collection period. Jack was continuing to have contact with his father and other members of that side of the family, including his father's sister who was police officer.

\section{Data Collection Activities}

Methods that are suggested to be particularly suitable for use with younger children include: drawing, photography, observations, semi-structured interviews, child conferencing, setting tours, and videos (Clark, 2005, Cook and Hess 2007, Einardottir 2005). The Mosaic Approach which utilises many of these activities was used (Clark and Moss 2001). Drawing, map-making, photography, observations and semi-structured interviews and child conferencing, a '...formal structure for talking to young 
children...' were adopted in this research (Clark and Moss 2001, 15). This paper reports data collected using photographs, observations and child conferences.

\section{Results}

This paper reports the findings based on data generated with three of the children. I began to utilise thematic coding as I observed the children playing, noticing the themes emerging. Such an approach is recognised as an effective way of coding qualitative and ethnographical data (Rivas 2012). Buckler and Walliman (2016) take this a stage further suggesting that the process of coding itself is analytical, it requires the researcher to review, select, interpret and summarise information without distorting it. I immersed myself in the data by reading and re-reading it, sometimes writing reflections in my field notes journal, on the data or the experiences that I had had in the settings to help me to get a feel for the data and to understand and recognise the themes that were emerging (Clough and Nutbrown 2007, Rivas 2012).

The three temporal states of being, becoming and having been are often seen to be integrated during children's play experiences. Six vignettes provide the data in which children are seen to demonstrate different temporal states often moving seamlessly between them during play episodes. Two vignettes offer evidence generated with Penny, three with Jack and one with Caleb

In this first scenario Penny stepped out of her play to engage me in conversation. She had identified that she would like to participate in the research and the necessary permissions had been sought and gained. The conversation that she had with me was purposive; I already knew which days that she attended the setting.

Vignette 1. Penny 
Field notes: Home-fell Nursery

Penny walked up and started a conversation with me.

"I don't come on Fridays, but I come on Wednesdays."

"You can talk to me on Wednesdays. You can play these instruments, play the

instruments." Penny insists that I play a series of musical instruments with her. She then dances whilst I played the instruments, some more children join in. The children were all dancing and insist that I danced too (which I did).

Penny stayed playing instruments when the others left. "Come on play the band," she shouted at me when she realised that I had stopped. Penny dances around the space but regularly returns to the mirror where she observes herself dancing. She seems to like to look at her dress and how it moves as she is dancing. Suddenly she puts her hood up.

"How do I look Zenna?"

"Very nice" [researcher].

She seems concerned with her image whilst dancing. She suddenly stops, moves to the table where the pegboard activity is laid out and immediately puts her hood down.

The following extract is part of the conference that I conducted with Penny looking at her photographs. One of the photographs that she identified as being important showed two children, Caleb and Holly.

Vignette 2: Penny

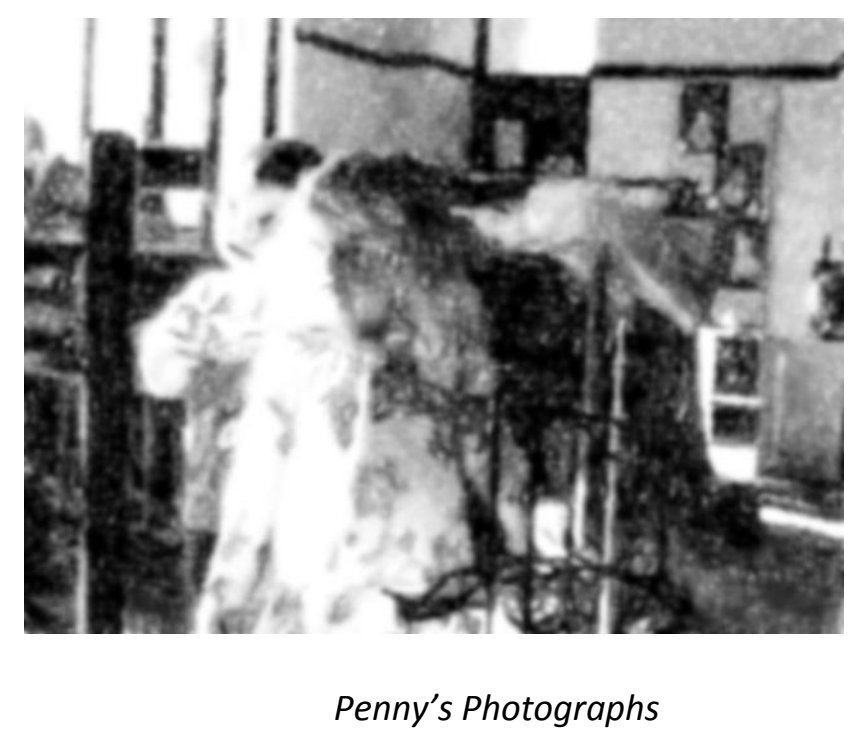

That's Holly and Caleb. I took lots of photos of Caleb because he's in blue in group. It's important because I'm in it. I'm a princess super-hero. Holly is my best friend. 
In the following scenario, Jack is engaged in a role-play scenario in which he is playing the role of a police officer, a theme that is repeated frequently through the research period.

Vignette 3: Jack

Field notes: All Hallows Pre-school

Play has moved outside. The 3 boys including Jack have police helmets on and are playing a police game. They are on ride-on cars and trikes. [Researcher: Are you arresting people?].

Yes, in cars and if someone's naughty I'll arrest them and put them in jail real. And then I'll get my gun and shoot them up.

[Researcher: Are you allowed to do that?]

Yes, my auntie says so.

[I suggest that they can't]

He insists that they can his auntie has told him so. He goes off on his trike.

In the ensuing field notes Jack can be seen to have left one play scenario to engage a member of staff in conversation. The conversation appears to demonstrate Jack's understanding of what his aunt had been doing whilst on duty as a police officer that weekend.

Vignette 4: Jack

Field notes: All Hallows Pre-school

Jack had been playing a game of police with a friend, he leaves the play and walks over to the setting manager Susan and says:

'My auntie didn't catch no baddies,' (he repeats this several times) 'I said what type of policewoman are you, you didn't catch no baddies?'

\{Susan\} 'Did you want her to arrest people?'

Jack: 'Yes I want her to catch the baddies.'

\{Susan\} 'Perhaps everyone was being good.' [Some missed dialogue.]

Jack: 'Someone-else was arresting baddies but she was just sitting and thinking. I was cross.'

\{Susan\} Why were you cross?

Jack: 'I want her to arrest baddies, what type of policewoman is she? I phoned my dad.

\{Susan\} 'Did you talk to him about it?

Jack: 'Yes and we phoned my auntie.'

\{Susan\} 'Ooh my you talked to everyone.' 
Jack: 'Yes we were all cross, my auntie was cross.'

\{Susan\} 'Oh she was cross too?'

Jack: 'Oh yes we were all cross.'

Jack then left with his friend both were still in role as policemen. They continued to look for people to arrest.

Jack chose to engage me in a conversation about his play, stepping in and out of role in order to do so.

Vignette 5: Jack

Field notes: All Hallows Pre-school

Jack and two friends are wearing police helmets.

[Yet the dressing-up clothes don't appear to be out].

They are engaging in a game police role-play. Jack walks over to me. 'We are real policemen and we put naughty people in jail. Look at my hat and the top.'

[Researcher: Is it a real police helmet?] 'Yes, and I've got handcuffs. I've got a gun too it's back at the police station.'

[Researcher: Oh, my goodness I hope it stays there.]

'I haven't got a gun so I'm going to have to make one - but it will shoot real. Are you naughty? [Jack arrests me, then lets me go]. 'We have to go someone else is being naughty.'

Jack leaves.

In the next scenario, a play activity was set up by a student. Several of the

children in the setting appeared interested in what she was doing and followed her into the role-play area to engage with her activity.

Vignette 6: Caleb

Field notes: Home-fell Nursery

A student went to the role-play area. 5 children went and joined her. They all gathered round the tills and showed an interest in the money.

Caleb and his friend chose to sit at the table and showed engagement with the tills, money and card machines. Percy demonstrated his understanding of scanning items. Caleb appeared to be counting the money. He tells the student, 'I have a mobile,' offering a card machine.

A child comes and takes the card that Caleb was swiping. Percy attempts to get it back and quickly takes the card to Caleb. Caleb then shares the card with Percy.

As the children bring Caleb items he scans them and asks for the money. \{He seems to use plausible amounts according to what is being purchased, for example 50p for a tin of beans.\} 
Caleb helps a child to put items into the basket.

\section{Discussion}

From the findings of the research, I argue that the children are enabled to demonstrate the integration of the three temporal states, beings, becomings and having beens through rich role-play opportunities (Cross 2011). Role-play provides opportunities that allow children exciting chances to step between the three states as they enact roles that are of interest to them now and may be of interest to them in the future. The peer cultures in which the children are situated forms an essential element of these play experiences and opportunities (Corsaro 2011).

The two vignettes of Penny demonstrate that she is aware of her own views and is both agentic and capable of sharing them with me as well as being keen to do so. In the first vignette she demonstrates that she was in control of the situation and moving between a conversation and a role-play scenario. Penny had identified herself as a child that would be interested in participating in the research; her behaviour demonstrates that she is a being child (James and Prout 1997). She clearly demonstrates that she is a capable social actor who is keen to comment on her life at the same time she moves seamlessly between temporal states (James and Prout 1997, Uprichard 2008, Cross 2011). She appeared to understand that her views were of importance to me and the way in which she spoke to me appeared to be suggesting that I needed to prepare myself and my research in order that I could work with her on the days that she would be in the setting. She appeared to move seamlessly between temporal states, she held her conversation with me as well as moving into role-play which appears to be informed by having been knowledge. During the dancing episodes, she was clearly concerned by her image and appeared to have an expectation of what she should look like. Penny appeared to engage in a stylised form of dancing in which a certain image needed to be 
maintained. As she moved on to work on the pegboard, she changed her appearance back to her pre-dancing dress. Whilst the play was occurring now, being, it was informed by previous experiences having been.

In the second vignette, we see Penny move between using narrative language and imaginative language, discussing who she can see and what she likes to do. She then comments on herself as being a princess super-hero. This appears to be something that she considers herself to be in the moment. Uprichard, $(2008,304)$ suggests that an approach that sees children as either, '... human 'beings, or human 'becomings' tends to involve conflicting approaches of what it means to be a child'. She suggests that these discourses should not be conflicting but as complementary. In integrating these two images of the child as both being and becoming, the child is afforded greater agency. The child is a child in the present but they will be an adult in the future, even very young children appear to understand the concept and are able to articulate it. When Penny looks at the photograph; she simply makes a statement about what she can see and why she took it. In that instance, she was being, in the moment. However she is both literal and non-literal, which again demonstrates different temporal states and utilizes her imagination. Her discussion of being a super-hero princess was influenced by knowledge that she already had, having been. Both being and having been are vital in allowing her opportunities to play and role-play.

Jack's three vignettes demonstrate his overarching interest in the police. In his first vignette Jack can be seen to draw on information that has been gathered from experience, from conversations with his aunt, as well as from his imagination. His knowledge from his aunt is his having been knowledge. Given his interest in the police he has clearly discussed with her what she does and what police officers can and cannot do. He is enacting the role of a police officer in his play, being. The two temporal states 
inform his play and he moves between them to continue the play theme. Jack appears to believe that his aunt has told him that as a police officer it is acceptable to shoot people who are not behaving in an appropriate manner, he therefore enacts this in his play. He refuses to be dissuaded from his position because he believes that he has been given this information by his aunt. Cross (2011) argues that children's behaviour in the present will be influenced by their experiences of the past and that this is true even for very young children. Jack's play appeared be influenced by his knowledge of his aunt's work, having been, it was occurring now, being, but also informed his future self, given that he regularly discussed his desire to be a police officer in the future, becoming. Jack's role-play appears to provide a clear illustration of his working and reworking of cultural meanings (Corsaro 2011, Wyness 2012). Jack's aunt is a policewoman and it appears that Jack would also like to join the police force when he is older. He spends much of his time in role-play enacting the role of a policeman. Children's pretence is usually grounded in reality and it is in this play that children begin to engage with the world around them and gain an understanding of the complex structures that it presents (Papadopoulou 2012). These pretend play episodes enable them to develop, '... the competences that are crucial for their successful cultural adaptation (576). Jack's conversation with the member of staff demonstrates that he is thinking about his aunt and her real-life experiences as a police-officer. Here again, Jack can be seen to be using his having been knowledge, his understanding of his aunt's role, to inform his thinking about what his aunt's responsibilities were whilst she was on duty (Cross 2011). He seemed extremely perturbed about the fact that she had not arrested anyone the last time she was on duty. This concern he explained at length to the staff as well as the fact that he had discussed the issue with his father and other members of his family. In his own play, he was regularly engaged in arresting his so- 
called baddies. Jack is aware that his aunt neither; arrests suspects as often as he does, nor does she carry a gun on the street. However, through his play he is able to reflect his understanding of her role. His role-play reflects an understanding of reality (Papadopoulou 2012).

Children draw on their knowledge, memories and previous experiences to enact their play. In the third vignette Jack spent time explaining to me that the plastic hat that he was wearing was a real police hat and that given he was a policeman he would also need a gun. There were no guns available in the setting, he gave an explanation that he would need to make one, but the made item would, 'shoot real'. Jack repeated the notion of it 'shooting real' several times. He later demonstrated that he had made a gun from interlocking plastic construction materials but again assured me that it would, 'shoot real.' What is clear from this is that Jack is thinking on several different levels (Bodrova and Leong, 2003, 2005, Leong and Bodrova 2012). Jack is operating on an imaginative level suggesting that his gun will, 'shoot real'. He is demonstrating his understanding of what a gun can and should do. Equally his use of the construction materials demonstrates that he is aware that he is creating something for which he will need to use his imagination to make his play more meaningful. Jack's use of construction materials mirrors that of children in the study by Broadhead and Burt $(2012,33)$ in which children were encouraged to use open-ended play materials to create, '... whatever you want it to be,' places and objects. Jack was planning his play, thinking about the role he would inhabit, using props, the hat and the gun, considering the language, talking about arresting people and developing an appropriate scenario. Much of this draws on Leong and Bodrova's (2012) PRoPELs in which children can extend their role-play and gain significant meaning from it. Jack is being a policeman now; he also intends to be becoming a policeman in the future. The 
temporality of his current state does not appear to register; Jack appears to see himself as a policeman now as well as in the future (James, Jenks and Prout 1998, Conrad 2011). It seems that Jack is both being and becoming with experience of having been (Cross 2011). He draws on conversations with his aunt and his father to ensure that his play and in particular his role-play is based in reality whilst also demonstrating an understanding of how he would like to be in the future. His knowledge about his aunt supports his imaginative role-play activities drawing on his having been self. Similarly, this informs his being self, he richly enacts the role of the police officer not simply imitating what he has seen but making it his own (Vygotsky 1978). It also informs his becoming self as he discusses what he will do in the future.

In all these scenarios Jack appears to juxtapose both his current, being and having been experience with his notion of his becoming or future self. Jack does appear keen to share his ideas about both what his aunt is doing now and what he will be doing in the future with members of the staff team and me. On several occasions, he was prepared to interrupt or step out of another role-play situation to have this discussion. Children have been constructed against a backdrop in which they are conceived of as incompetent and needing the support of adults until such a time as they have become adults in their own right (Lee 2001). Jack does appear to seek the approbation of adults in these interactions, yet at the same time it can be argued that in a setting where the children are encouraged to demonstrate their views and ideas they are also being supported to move between the three temporal states; beings, becomings, and having beens and to use this knowledge and these experiences to support the development of rich play experience (Cross 2011, Rogers and Evans 2008, James, Jenks and Prout 1998, Cosaro 2011). 
Vignette 6 describes some of Caleb's play as he role-plays being a shopkeeper. Like Jack, Caleb can draw on having been knowledge to inform his role-play drawing on his own experiences of being in the shop with his father. Caleb appeared self-assured in this role-play scenario; scanning items confidently, asking for money using plausible amounts, using a credit card and placing items into bags and baskets. In much of this scenario he is seen to draw on reality to inform his play. He is also making the play his own by engaging in object substitution, using a card and suggesting that it was a mobile phone (Papadopoulou 2012, Vygotsky 1978 Vig 2007, Frahsek et al 2010).

Role-play provides opportunities for children to demonstrate the integration of the three selves as; beings, becomings and having beens, in meaningful ways. In these, often complex, play scenarios being, becoming and having been selves, are often in evidence. Whilst fantasy themes are offered in role-play areas to children, it is more usual to find that day-to-day scenarios such as shops, hospitals, cafes, travel agencies and vets are what are on offer to the children and it is in these day-to-day scenarios children can draw on their having been knowledge to support and develop their play (Rogers and Evans 2008, Cross 2011). Certainly, during the period of research at both All Hallows Pre-school and at Home-fell Nursery straightforward literal scenes were provided. Whilst the children were often engaged in a complex game in which there was an element of fantasy, their play scenario was grounded in real experiences (Papadopoulou 2012). The rich experiences that are stored in their memory and link with having been knowledge, allow them to plan their play and the roles that they will enact (Cross, 2011, Leong and Bodrova 2012). Role-play appears to reflect all three domains of being, becoming and having been it provides rich opportunities for children to enact a range of roles demonstrating their integrated temporal states as beings, becomings and having-beens, as well as providing opportunities for children to move 
between temporal states and to demonstrate themselves as fully integrated individuals. This is turn has implications for practice. It seems essential that practitioners develop a good understanding of the three temporal stances in which children operate and the ways in which this impacts on their constructions of self. The notion of self is an element of personal, social, and emotional development (PSED) within the Early Years Foundation Stage (EYFS) (DfE 2012). It was been identified by Tickell (2011) in her review of the initial EYFS (DCSF 2008) as an essential element of early childhood. There is therefore, an overlap between policy and practice in that PSED is enshrined in practice and a good understanding of how it is supported in practice is necessary in order that children can be supported to develop a sense of self.

\section{Conclusions}

In this paper, I set out to explore the notions of being, becoming and having been, considering how these themes can be identified through children's play and role-play activities (Cross 2011). Role-play allows children opportunities to understand complex structures of the world around them drawing on being, becoming and having been knowledge (Uprichard 2008, 2010, Cross 2011). Rich role-play experiences appear to allow for an integration of the three temporal states. The children use their knowledge and experiences to develop and inform their roles as well as to allow them to inhabit possible future roles. Jack repeatedly utilised his knowledge of work undertaken by his aunt, a policewoman, to inform his role-play. Similarly, he would use this as a basis for discussing the roles that he hopes to inhabit in the future. The role-play allowed the children to develop rich scripts whilst integrating being, becoming and having been (Cross 2011, Rogers and Evans 2008).

Framing children as integrated beings who are; beings, becomings and having beens allows for a more appropriate construction of the child in which they are 
recognised as being agentic in their own lives, capable individuals who can comment on their experiences and future desires which has implications for both policy and practice. The children appear to embody more than one temporal state at any one time, stepping between them seamlessly. From the data, I have shown that rich role-play experiences allow for an integration of the three selves, children draw on their experiences to inform their play.

\section{References:}

Ainsworth, M. D. S., \& Bell, S. M. 1970 ‘Attachment, exploration, and separation: Illustrated by the behavior of one-year-olds in a strange situation'. Child Development, 41:49-67.

Bodrova, E. and Leong, D. 2003 ‘Building Language \& Literacy Through Play’. Early Childhood Today, 18(2): 34.

Bodrova, E. and Leong, D. 2005 'Uniquely Pre-school’ Educational Leadership, 63(1): 44-47.

Bowlby, J. 1952 ‘Maternal Care and Mental Health’. World Health Organisation, Geneva.

Brannen, J. 2004 'Childhoods across the generations: Stories from women in four generation English families'. Childhood, 2004(11): 409-428.

Broadhead, P. and Burt, A. 2012 Understanding young children's Learning through Play: Building Playful Pedagogies. London: Routledge.

Buckler, S. and Walliman, N. 2016 Your dissertation in education 2e. London: Sage. Christensen, P. 2004 'Children's Participation in Ethnographic Research: Issues of Power and Representation', Children and Society 18 (2004): 165-176.

Clark, A. 2011 'Breaking methodological boundaries? Exploring visual, 
participatory methods with adults and young children', European Early Childhood Education Research Journal, 19(3): 321-330.

Clark, A Flewitt, R. Hammersly, M. and Robb, M. 2014 Understanding Research with Children and Young People. London: Sage.

Clark, A. and Moss, P. 2001 Listening to children: The Mosaic Approach. London: Joseph Rowntree Foundation.

Clough, P and Nutbrown, C 2007 A student's guide to methodology. London: Sage. Conrad, R. 2011 'My future doesn’t know ME: Time and subjectivity in poetry by young people'. Childhood, 19(204): 204-217.

Cook, T. and Hess, E. 2007 'What the Camera Sees and from Whose Perspective: Fun methodologies for engaging children in enlightening adults'. Childhood,14(29): 29-45. Corsaro, W. 2011 The Sociology of Childhood 3rd ed. London: Sage.

Cross, B. 2011 'Becoming, Being and Having Been: Practitioner Perspectives on Temporal Stances and Participation across Children's Services'. Children and Society, 25: $26-36$

DCSF 2008 Statutory Framework for the Early Years Foundation Stage. London: DCSF.

DfE 2012 Statutory Framework for the Early Years Foundation Stage. Runcorn: DfE. Ebrahim, H. 2011 'Children as agents in early childhood education'. Education as Change, 15(1): 121-131.

Frahsek, S. Mack, W. Mack, C. Pfalz-Blezinger, C. and Knopf, M. 2010 ‘Assessing different aspects of pretend play within a play setting: Towards a standardized assessment of pretend play in young children'. British Journal of Developmental Psychology, 28: 331-345.

James, A. Jenks, C. and Prout, A. 1998 Theorizing Childhood. Cambridge: Polity Press. 
Kay, E. and Tisdall, M. 2012 'The Challenge and the Challenging of Childhood Studies? Learning from Disability Studies and Research with Disabled Children'. Children and Society, 26: 181-191.

Lee, N. 2001 Childhood and society: growing up in an age of uncertainty. Buckingham: OUP.

Leong, D. and Bodrova, E. 2012 ‘Assessing and Scaffolding Make-Believe Play’. Young Children, 67(1): 28-34.

Mayall, B. 2002 Towards a Sociology for Childhood thinking from children's lives. Maidenhead: OUP.

Papadopoulou, M. 2012 'The ecology of role play: intentionality and cultural evolution'. British Educational Research Journal, 38(4): 575-592.

Piaget, J. 1959 The Language and Thought of the Child. London: Routledge Kegan Paul.

Prout, A. and James, A. 1997 ‘A New Paradigm for the Sociology of Childhood?

Provenance, Promise, Problems', in Constructing and Reconstructing Childhood Contemporary issues in the Sociological Study of Childhood edited by James, A. and A. Prout, 7 - 33. London: Falmer Press.

Qvortrup, J. 2004 'Editorial: The Waiting Child'. Childhood. 11: 267-273.

Rankin, B. 2004 'The importance of intentional socialisation among children in small groups: A conversation with Loris Malaguzzi'. Early Childhood Education Journal, 32(2): $81-85$.

Rivas, C. 2012 'Coding and Analysing Qualitative data', in 2012 Researching Society and Culture, edited by Clive Seale, London: Sage.

Rogers, S. and Evans, J. 2008 Inside Role-Play in Early Childhood Education. London: Routledge. 
Stratigos, T. 2015 'Assemblages of desire: Infants, bear caves and belonging in early childhood education and care' Contemporary Issues in Early Childhood, 16(1): 42-54. Tickell, C. (2011) The Early Years: Foundations for life, health and learning. [online] Available from:

https://assets.publishing.service.gov.uk/government/uploads/system/uploads/attachment _data/file/180919/DFE-00177-2011.pdf [accessed] 12/06/18.

Tillett, V. \& Wong, S. 2018 ‘An investigative case study into early childhood educators" understanding about "belonging", European Early Childhood Education Research Journal, 26(1): 37-49.

Uprichard, E. 2008 'Children as "Being and Becomings": Children, Childhood and Temporality'. Children and Society, 22(4): 303 - 313.

Vig, S. 2007 'Young Children's Object Play: A window on Development'. Journal of Development and Physical Disabilities, 19: 201-215.

Vygotsky, L. 2004 'Imagination and Creativity in Early Childhood'. Journal of Russian and East European Psychology, 42(1): 7-97.

Wyness, M. 2006 Childhood and society: an introduction to the sociology of childhood. Basingstoke: Palgrave Macmillan.

Wyness M. 201 Childhood and society. Basingstoke: Palgrave Macmillan. 